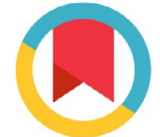

Check for updates
${ }^{\star}$ For correspondence:

alesaleh70@yahoo.com

Competing interests: The authors declare that no competing interests exist.

Received: 02 August 2017

Accepted: 18 September 2017

Published: 29 September 2017

Copyright The Author(s) 2017. This article is published with open access by BiolMedPress.

This article is distributed under the terms of the Creative Commons Attribution License (CC-BY 4.0) which permits any use, distribution, and reproduction in any medium, provided the original author(s) and the source are credited.

\section{Essentials of bladder cancer worldwide: incidence, mortality rate and risk factors}

\author{
Hamidreza Sadeghi Gandomani1,2, Abed Asgari Tarazoj33, Fatemeh \\ Hadavand Siri4, Ali karimi Rozveh5, Soheila Hosseini6, Narges Naseri

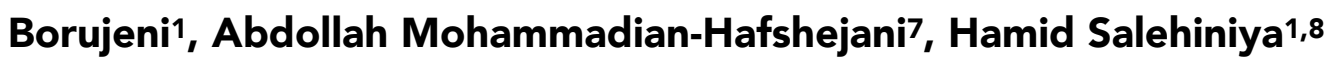

\author{
'Zabol University of Medical Sciences, Zabol, Iran \\ ${ }^{2}$ Trauma Nursing Research Center, School of Nursing and Midwifery, Kashan University of \\ Medical Sciences, Kashan, Iran \\ ${ }^{3}$ Department Of Nursing, College of Nursing, Naragh Branch, Islamic Azad University, \\ Naragh, Iran \\ ${ }^{4}$ Shahid Beheshti University of Medical Sciences, Tehran, Iran \\ ${ }^{5}$ School of Nursing and Midwifery, Tehran University of Medical Sciences, Tehran, Iran \\ ${ }^{6}$ School of Nursing and Midwifery, Gorgan University of Medical Sciences, Gorgan, Iran \\ ${ }^{7}$ Department of Epidemiology and Biostatistics, School of Health, Shahrekord University \\ of Medical Sciences, Shahrekord, Iran \\ ${ }^{8}$ Department of Epidemiology and Biostatistics, Tehran University of Medical Sciences, \\ Tehran, Iran
}

\begin{abstract}
Bladder cancer (BC) is the sixth most common cancer in the world. An increase in the incidence and recurrence of $\mathrm{BC}$ has led to massive pressure on health care systems. Studies have shown that the geographical and ethical distributions of $\mathrm{BC}$ are variable in different parts of the world. However, most studies have focused more on clinical challenges and treatment strategies in BC management. Due to the limited number of studies conducted on the incidence rate, mortality and risk factors of $\mathrm{BC}$ worldwide, it is necessary to carry out studies in these areas. Therefore, the aim of this study was to determine the global incidence rate, mortality rate and risk factors for BC.
\end{abstract}

\section{Keywords}

Bladder cancer, Incidence, Mortality, Patient, Risk Factor, World 


\section{Introduction}

$\mathrm{BC}$ is the 6th most common cancer in the world, the 7th most common cancer in men, and the $17^{\text {th }}$ most common cancer in women (Burger et al., 2013). The increase in the incidence rate of $\mathrm{BC}$ and its recurrent nature have led to massive pressures on health care systems (Sievert et al., 2009). The American Cancer Society in 2017 estimated there to be 79,030 new cases of BC and 16,870 deaths from it in the United States ([Internet], 2017). The rate of BC diagnosis in men is 4 times greater than in women and the 5 -year survival rate varies from 40-80\% (Ranasinghe et al., 2012). Nevertheless, during the last two decades, BC rates have been steady in men while there has been a $0.2 \%$ annual increase in women ([Internet], 2017).

Research findings have shown that the geographical and racial distributions of $B C$ varies in different parts of the world; for instance, it is more dominant in American countries than in Asian countries (Colombel et al., 2008). Significant geographical changes in the incidence rates of $\mathrm{BC}$ indicates that various factors influence the increase of BC. However, most studies in this field have focused more on clinical challenges and treatment strategies in BC management (Feifer et al., 2011; Simone and Gallucci, 2012; Sylvester, 2011). Due to the limited number of studies conducted on the incidence, mortality and risk factors of BC worldwide, it is necessary to conduct studies in these areas. Therefore, the purpose of this study was to evaluate the incidence, mortality rate and risk factors of BC worldwide.

\section{Methods}

This review study was conducted on all studies published in English and before January 2017. The following databases were searched: PubMed, Embase, Scopus, and Science Direct. The search strategy included key words of "bladder cancer", "epidemiology", "incidence", "mortality", "risk factors", and "world". The search strategy was tailored due to the requirements of each database. An advanced search was also carried out in cancer-related websites to access specific information for each country.

\section{Results}

\section{The incidence and mortality rates of $B C$ in the world}

The incidence of $\mathrm{BC}$ varies considerably according to the geographical area, with the highest age-standardized incidence rate of 17.5 cases in Belgium (Jemal et al., 2010), 16.6 in Lebanon (Shamseddine et al., 2014), 15.8 in Malta (Torre et al., 2015), 15.2 in Turkey (Antoni et al., 2017), and 14.4 in Denmark (Ferlay et al., 2013), per 100,000 people. Also, the 5 countries with the highest standardized 
incidence rate in males were: Belgium- with 31 (Jemal et al., 2010), Lebanonwith 29.1 (Shamseddine et al., 2014), Turkey- with 28.7 (Antoni et al., 2017), Armenia- with 27.3 (Mahdavifar et al., 2016), and Malta- with 26.9 (Torre et al., 2015) cases, per 100,000 people. Also, the 5 countries with the highest agestandardized incidence rate of $\mathrm{BC}$ in women were: Hungary- with 7.4, Denmarkwith 7 (Ferlay et al., 2013), Norway- with 6.4 (Jemal et al., 2011), Belgium- with 6.2 (Jemal et al., 2010), and Malta- with 6.2 (Torre et al., 2015) cases, per 100,000 people. The rate of BC in males is 4 times higher than in females (Kirkali et al., 2005).

The standardized mortality rate of BC varies from 2-10 for every 100,000 per year in men and 0.5-4 for every 100,000 per year in women (Mahdavifar et al., 2016). BC in women is not among the ten most common cancers. Therefore, it is expected that for 2016, the mortality rate of BC in men would be higher than in women; indeed, reports indicated 11,820 cases in men and 4,570 cases in women (Scosyrev et al., 2009). The comparative higher rate of BC in men versus women could be due to differences in smoking habits and occupation (which are two common risk factors for BC) (Freedman et al., 2011). However, over the past two decades $B C$ rates have been steady in men, but have risen by $0.2 \%$ in women (Burger et al., 2013).

Studies have shown that with increasing number of deliveries, the incidence of $\mathrm{BC}$ decreases. Also, $\mathrm{BC}$ rates in women who have had a single delivery are lower than those who have not yet given birth; pregnancy-induced hormonal changes seem to act as a protective factor in women (Dietrich et al., 2011). Indeed, the findings of an animal study showed that rats treated with androgen hormones were more likely to have bladder tumors than rats treated with estrogen hormones (Reid et al., 1984). This finding, therefore, suggests that some androgenic hormones stimulate oncogenesis while estrogen hormones are protective (Davis-Dao et al., 2011). Furthermore, BC rarely occurs at the ages of 40-50; the average age of $B C$ diagnosis is 69 in men and 71 in women (Letašiová et al., 2012).

The incidence of $\mathrm{BC}$ has recently decreased in some countries, which may be due to differences in recording or reporting low-grade tumors (Jemal et al., 2010) and the reduction of exposure to risk factors (mainly due to reduced smoking and improved occupational health) (Bosetti et al., 2011). However, there is no similar trend of $B C$ incidence. For instance, the age-standardized rate of $B C$ has declined in the United Kingdom while at the same time it has remained constant in America among white Americans (Burger et al., 2013). BC is the $4^{\text {th }}$ most common cancer in men in the United States (Koay et al., 2011). The incidence of $\mathrm{BC}$ in white men is twice that of black men. However, the prognosis of BC in black patients is worse than white patients (Yee et al., 2011). The highest standardized mortality rates were 6.6 in Turkey (Antoni et al., 2017), 6.5 in Egypt (Chavan et al., 2014), 6.3 in Iraq (Mahdavifar et al., 2016), 6.3 in Lebanon (Mahdavifar et al., 2016), and 5.2 in Mali (Chavan et al., 2014), per 100,000 people. The 5 countries with the highest standardized mortality rates in 
males were: Turkey- with 12.8 (Torre et al., 2015), Iraq- with 11.4 (Mahdavifar et al., 2016), Armenia- with 1.3 (Pakzad et al., 2015), Egypt- with 11.1 (Chavan et al., 2014), and Lebanon- with 11 cases (Mahdavifar et al., 2016), per 100,000 people. The 5 countries with the highest standardized mortality rates among women were: Mali- with 4.4 (Chavan et al., 2014), Malawi- with 4.4 (Antoni et al., 2017), Malta- with 4.3 (Jemal et al., 2010), French Polynesia- with 2.9 (Mahdavifar et al., 2016), and Iraq- with 2.9 (Mahdavifar et al., 2016), per 100,000 people (Mahdavifar et al., 2016).

\section{$\mathrm{BC}$ risk factors}

\section{1-Smoking}

Tobacco use is one of the primary and common risk factors of BC in the world, especially in the United States, and it has also become a concern in developing countries (Letašiová et al., 2012). Other BC risk factors include use of pipe and secondhand smoke. The findings of a meta-analysis study showed that the risk of developing $B C$ in smokers was 3 times higher than non-smokers. Findings from studies have shown that there is a direct correlation between the number of cigarettes, the duration, and severity of smoking with the risk of $\mathrm{BC}$ in both sexes ([Internet], 2017; Escudero et al., 2011; Freedman et al., 2011). A study by Zeegers et al. which assessed the etiological fraction of smoking showed that cigarette consumption is responsible for $23 \%$ of $\mathrm{BC}$ cases in women and $50 \%$ of cases in men (Zeegers et al., 2004). The precise mechanism of BC induction by the use of cigarettes is not known but it seems that the risk of $B C$ is related to some of the chemicals found in cigarettes, such as naphthylamine-2, aminobiphenyl-4 and polycyclic aromatic hydrocarbons (Baris et al., 2009). Tobacco flares, including nitrosamine, polycyclic aromatic hydrocarbons, 2naphthylamine and other aromatic amines, all playing a role as direct mutagenic agents in BC formation and in the release of at least 69 carcinogens (Kiriluk et al., 2012). Notably, the main pathways for inducing cancer in smokers are through the formation of adduct DNA and via genetic damage, which cause changes in specific cellular pathways and consequently uncontrolled cell growth and inhibition of tumor growth inhibitory mechanisms (Alberg and Hébert, 2009).

\section{2-Occupational factors}

\section{2-1. Aromatic amines}

The most important risk factor for developing BC after smoking is exposure to aromatic amines, which include 2-naphthylamine, 4-aminophyenyl, and benzidine (García-Pérez et al., 2009). These compounds are found in dyes, chemical compounds, rubber, hair coloring dyes, cigarette smoke, plastics, vehicle smoke, paint products, and fungicides (Letašiová et al., 2012). Findings of occupational cohort studies have indicated an increased risk of non-smoking BC in individuals exposed to aromatic amines, including people working in 
different industries such as rubber and leather producers, weavers, colored product workers, and printing companies (Carreón et al., 2010; Pira et al., 2010). Recently, due to increased awareness by individuals about safety principles, the extent and pattern of exposure to occupational hazards have improved (Kogevinas M, 2014).

Occupational exposure to aromatic amines occurs mainly through skin contact (García-Pérez et al., 2009) and are correlated with increased risk for BC. Findings of two cohort studies showed that the risk of BC increased in individuals exposed to 1-naphthylamine, 2-naphthylamine, benzidine, and 4-aminobiphenyl over a period of 60 years (Case and Hosker, 1954; Melick et al., 1955). Findings from a case-control study by Samniac et al. showed that the risk of BC in men employed in the printing industry as machine operators (case group) was significantly higher than that for the control group (Colt et al., 2010). Also, Case et al. found that the BC risk in British staff exposed to 2-naphthylamine was 200 times higher than other staff (Case and Hosker, 1954). Moreover, the findings of a cohort study performed on 11,000 cases of rubber industry workers also showed that the standardized mortality ratio (SMR) of BC in maintenance, transportation, and general staff increased in this industry (159, 95\%, Cl 92-279). A study in 171 workers in the rubber industry showed that 19 cases of BC were diagnosed in the workers (Golka et al., 2004). In fact, 4-aminobiphenyl (aromatic amine) is as a carcinogen of smoke tobacco which is used in the rubber industry too and benzidine (in dyed products used in the rubber industry) is the most important carcinogenic aromatic amine associated with bladder damage. Moreover, the results of a cohort study of 784 workers in China showed that the risk of BC in these individuals increased 35-fold (Gago-Dominguez et al., 2001). Those individuals, especially barbers, who are exposed to hair dye and cosmetics are more prone to have BC (Letašiová et al., 2012). As the findings of the Golka study showed, the risk of BC has increased (Odds Ratio (OR): 1.9; $95 \%$ $\mathrm{Cl}: 1.1-3.3)$ in people who regularly use hair colors at least once a month for 1 year or more (Golka et al., 2004). Also, for people who regularly use hair color at least once a month for 15 years or more, the risk of $\mathrm{BC}$ is 3.33 times higher than other people (95\% Cl: 1.3-4.8) (Golka et al., 2004).

\section{2-2. 4,4'-Methylene-bis(2-chloroaniline) (MBOCA)}

One of the chemicals used as a therapeutic agent in polyurethane products is 4,4'-methylene-bis(2-chloroaniline) (MBOCA). The highest risk of exposure to MBOCA is in workers who absorb MBOCA vapor or dusts through the skin, or inhale MBOC dusts (Chen et al., 2014). Findings from studies have shown that moderate and chronic exposure to MBOCA can cause bladder tumors (Chen et al., 2014; Kiriluk et al., 2012; Lin et al., 2013).

\section{3-Genetic susceptibility}

People with family members having $B C$ are at greater risk for $B C$ since $B C$ risk is twice as high in first degree relatives than in other patients (Burger et al., 2013). 
One of the reasons for this correlation is that family members are exposed to the same risk factors (such as those who are exposed to tobacco smoke). Among the risk factors of BC risk factors, hereditary genetic changes (such as changes in acetylator $\mathrm{N}$-acetyltransferase 2 (NAT2) and glutathione S-transferase mu1 (GSTM1)-null genotypes) make it difficult to decompose some of the toxins in the body and thus lead to BC (Kiemeney et al., 2010; Volanis et al., 2010).

\section{4-Nutritional factors}

Lack of adequate fluid intake, especially water, increases the risk of BC. Bladder vacancy seems to cause chemical accumulation due to delay in the removal of bladder waste, leading to increased risk of BC. In other words, increasing the amount of fluid intake (e.g. by diluting the urine) and increasing the micturition will reduce exposure of the urothelial tissue to carcinogens (Ros et al., 2011). Vitamin $D$ is one of the complementary ingredients which may reduce cancer incidence. The findings of a prospective study on male smokers showed that BC risk has a significant relationship with vitamin D deficiency (Garland et al., 1985). The findings of several case-control studies also showed that the risk of $B C$ in subjects receiving vitamin $D$ and those exposed to ultraviolet $B$ (UVB) was significantly lower than in control group (Brinkman et al., 2010; Chen et al., 2010; Mohr et al., 2010).

Overall, despite all the supporting evidence, there is a need for more clinical trials to confirm the role of vitamin $D$ in reducing $B C$ incidence. Taking nutritional supplements containing aristolochic acid (from the Aristolochia family) is also associated with an increased risk of BC (Chen et al., 2013). Aristolochic acid contains wild ginger, which is one of the main causes of kidney damage and urinary tract cancer (Chen et al., 2012). Despite its prohibition, it is still used in China as an herbal remedy for weight loss, rheumatism, and diminishment of menstrual disorders (Clyne, 2013).

Additionally, the type of ingredients in drinking water, such as arsenic and disinfectants, can affect BC risk. Among the potential sources of arsenic, we can point to water, cigarette, air pollution, glass products, and insecticides (Kiriluk et al., 2012). Arsenic in drinking water is a risk factor for BC in many parts of the world (Naranmandura et al., 2011). The chances of exposure to arsenic depends on the living conditions, such as whether they receive their drinking water from public and sanitary systems; this possibility is low in accordance with the standards defined by arsenic (Fernández et al., 2012). The findings from a casecontrol study in Main-New Hampshire-Vermont showed that there is a link between low to moderate levels of arsenic in drinking water and the risk of $\mathrm{BC}$; the daily BC rate in these individuals is $20 \%$ higher than the United States population ([Internet], 2017). Another source of arsenic is arsenic-based pesticides widely used on products (e.g. apples, tomatoes, and cornelian cherries) between the 1920s and 1950s (Jomova et al., 2011; Letašiová et al., 2012). 
The concentration of arsenic in groundwater and soil surface is high in countries such as China, Hungary, India, and Hungary (Peralta-Videa et al., 2009). Studies show that long-term consumption of water containing high levels of arsenic (greater than $0.2 \mathrm{mg} / \mathrm{L}$ ) is associated with $\mathrm{BC}$, while concentrations less than 0.1 do not show a clear correlation (Meliker et al., 2010; Steinmaus et al., 2003). Findings of a study in Bangladesh showed that mortality risks doubled after consumption of arsenic-contaminated water (Burger et al., 2013). In a recent Chilean analysis, it was found that after 20 years of discontinuation of arseniccontaminated water use, mortality rates were significantly higher in contaminated areas (Hazard Ratio (HR): 3.6; 95\% Cl: 3-4.7) (Fernández et al., 2012). The mechanism of $B C$ induction through arsenic is uncertain, but it seems that arsenic increases the risk of $\mathrm{BC}$ through indirect inhibition of sulfhydrylcontaining enzymes, interference with cytotoxic metabolism, genotoxicity, and inhibition of enzymes that play an antioxidant role (Tapio and Grosche, 2006). Importantly, p53 protein plays a role in the development of BC. Indeed, findings from a study in Taiwan showed that individuals exposed to arsenic have a gene mutation in the p53 gene in codon 175 and a transition occurring in 9 and 10 section (Letašiová et al., 2012).

Other potential carcinogens include nitrite and nitrate. Human contact with nitrite and nitrate is mainly due to food intake; nitrates are found especially in vegetables, processed meat, and contaminated water. The findings of studies on the relationship between excessive consumption of nitrate and $\mathrm{BC}$ induction are unclear (Chiu et al., 2007; Ward et al., 2003; Zeegers et al., 2006). A study in Slovakia showed that no correlation was found between nitrate and kidney cancer or bladder cancer (Gulis et al., 2002). However, a study on more than 40,000 women in lowa showed that there is a positive correlation between high concentration of nitrates in drinking water and the risk of developing $B C$ in these areas (W., 2001). Other cohort study findings on 21,977 old women in lowa, who used a high concentration of nitrate water for more than 10 years, showed that the incidence of $B C$ in them was 2.8 times greater than in other women (Weyer et al., 2001). Other studies indicate that nitrosamines may act as a carcinogens since they are a byproduct of urinary tract infection (and nitrite-producing organisms); however, there is not enough evidence to support this study (Botelho et al., 2011). Therefore, given the controversial findings in this regard, further studies are needed to confirm the effect of nitrates on increasing BC incidence.

\section{5-Age, sex, ethnicity, race, and socio-economic status}

In terms of age, BC risk increases in the elderly; in fact, $90 \%$ of BC cases occur in people over the age of 55 while the average age for $\mathrm{BC}$ diagnosis is 73 (Kiriluk et al., 2012). In terms of sex, the incidence of $B C$ in men is higher than in women; some studies have reported the incidence in men to be 4 times higher. However, mortality rates in women are higher than in men (Ranasinghe et al., 2012). It seems that one main reason for the lower incidence of BC in women is the lower prevalence of smoking and lower occupational risk in women (Burger 
et al., 2013). The reasons for the higher mortality rate in women, however, remains unclear.

The risk of $B C$ is two times higher in Whites than in African Americans. In the United States, the age-standardized rates for African Americans are 13 per 100,000 and for Whites are 22 per 100,000 (Yee et al., 2011). BC rates are lower in Asian Americans, Indian Americans, and Spaniards than other races. The causes of these differences are not well-defined (Scosyrev et al., 2009). Additionally, the findings from the Datta study showed that there is a significant relationship between marital status and survival rate of $B C$, independent of other factors like race, socioeconomic status, diseases or aggressive treatments; indeed, survival rates in married men are higher than in unmarried ones (Datta et al., 2009). Findings of the Koroukian study showed that there is a relationship between low socio-economic status and the unsustainable survival of BC (Koroukian et al., 2010). It seems that lack of access to healthcare and health services, as well as the increased risk of smoking in groups with a low socioeconomic status, account for the connection.

\section{6-Medical conditions}

One of the causes of $B C$ in developing countries, especially the Middle East, is infection with Schistosoma haematobium. A study in Egypt showed that $82 \%$ of BC patients carry $S$. haematobium eggs in their bladder. It should be noted that in young people with eggs in their bladders (positive eggs), the tendency to spread the tumor is greater than others (Botelho et al., 2009). In addition to $S$. haematobium, other species (including S. Mansoni and S. Japonicum) also contribute to the development of schistosomiasis in humans. Schistosoma is implanted in the bladder tissue, causing a chronic cyst and eventually BC ([Internet], 2017). Schistosomiasis is predominantly spread in African countries and some Asian countries, such as Iran, Iraq, Syria, Lebanon, Saudi Arabia, southern Portugal, Greece, and India (Mumbai). Infection rates have been reported in some countries, such as Egypt, up to 95\%. In this regard, in Egypt, the incidence of BC accounts for $16.2 \%$ of all cancers, while in America BC accounts for only $7 \%$ of all cancers in men (Kiriluk et al., 2012). One of the other medical causes of BC is infection with the Human Papilloma Virus (HPV). Various studies in different parts of the world indicate the existence of an association between anogenital HPV types 16 and 18 with BC (Husain et al., 2009; Noël et al., 1994) since HPV16 and HPV18 encode E6 and E7 oncoproteins. The E6 and E7 proteins are able to bind to cellular anti-tumor factors, such as p105RB and p53, and finally by inhibiting the function of these proteins they cause permanent cell life (Li et al., 2011). HPV types are classified into 3 classes based on their oncogenic potential: low risk (types 6, 11, 42, 43, 44, 59, 66, 68 and 70), moderate risk (types 30, 31, 33, 34, 35, 39, 40, 49, 51, 52, 53, 57, 58, 63 and 64), and high risk (types 16, 18, 45 and 46). High and moderate risk types with other cofactors are responsible for more than $90 \%$ of cases of malignant anogenital tumors (Kiriluk et al., 2012). 
The precise mechanism of carcinogenesis due to high-risk infections, especially of HPV16, is not entirely clear. HPV is capable of producing Acuminatum Condyloma (an anogenital ulcer) in the genital and bladder regions. It is a sexually transmitted disease and can be a risk factor for plate changes in the bladder epithelium, resulting in bladder carcinoma (Aglianò et al., 1994; Baithun et al., 1998; Karagas et al., 2005). Findings by Barghi et al. (Barghi et al., 2012) and Youshya et al. (Youshya et al., 2005) have indicated that the prevalence of HPV in BC patients are $35.6 \%$ and $34.7 \%$, respectively. Furthermore, a metaanalysis study showed that HPV, especially type 16 , may play a role in BC (Li et al., 2011). Radiation-related malignant tumors also usually cause secondary cancers after treatment of primary tumors. Patients undergoing radiation therapy for pelvic malignancies, including prostate, endometrial and cervical cancer, are prone to BC risk (Brown et al., 2010; Burger et al., 2013). Indeed, the standardized $B C$ rate increased in patients with prostate cancer treated with radiation (HR: 1.7; 95\% Cl: 1.57-1.86) (Abern et al., 2013). Nevertheless, BC associated with radiation therapy has been significantly reduced due to advances in radiation therapy techniques and limiting organs exposed to radiotherapy (Kiriluk et al., 2012).

In spite of the use of alkaline agents, including chemotherapy drugs for the treatment of malignancies and rheumatologic diseases, only oxazaphosphorines are associated with BC and hemorrhagic cystitis. One of the most famous oxazaphosphorine drugs is cyclophosphamide (Cytoxan), which is mainly used in lymphoma and leukemia (Emadi et al., 2009; Monach et al., 2010). Taking longterm chemotherapy drugs, such as cyclophosphamide, gives rise to acrolein (a cyclophosphamide metabolite) which stimulates the bladder and increases the risk of $\mathrm{BC}$. Therefore, in order to prevent bladder excitation in these patients, it is recommended that they receive a lot of fluids after taking such drugs (Figueroa et al., 2015; Monach et al., 2010). The infection with BC is higher in patients treated with immunosuppressive drugs than in other patients. In this regard, findings from a retrospective study on 3,000 recipients of kidney transplant showed that the risk of developing $B C$ in these patients increased by 3.3 times due to the use of suppressive drugs (Dietrich et al., 2011). Findings of other studies also showed that the risk of BC in kidney transplant patients is higher than that of end-stage renal disease (ESRD) (Miao et al., 2009; Vajdic et al., 2006). This could be due to long-term use of oral glucocorticoid drugs. Further studies are underway to investigate the mechanism of BC infection by immunosuppressive drugs.

Additionally, the use of anti-diabetic medications, such as pioglitazone (Actos), for a long period of time (more than 1 year) is also associated with an increased risk of $\mathrm{BC}$ (HR: $1.4 ; 95 \% \mathrm{Cl}: 1.03-2.0)$ (90). The findings of a cohort study indicated that the incidence of $\mathrm{BC}$ was increased with long-term intake of pioglitazone in diabetic patients (HR: 2.2; 95\% Cl: 1.3-8.3) (Lewis et al., 2011). Therefore, the Food and Drug Administration has forbidden the use of this drug in diabetic patients with $\mathrm{BC}$, and recommends caution when using this drug in patients who have a history of BC (Levin et al., 2015). There is a need for further 
studies to determine the potential impact of taking this drug and BC. Chronic secondary cysts (potentially leading to $\mathrm{BC}$ ) are associated with the use of persistent catheters, and kidney and bladder stones are also associated with $B C$ (Chow et al., 2010). Although BC levels have been reported to be greater than $10 \%$ in paraplegic patients using persistent urine catheters, from the use of alternative bladder evacuation methods the $\mathrm{BC}$ rates in these patients have been significantly reduced (Kiriluk et al., 2012; Pannek, 2002). Therefore, considering the presence of $\mathrm{BC}$ risk in people with permanent urinary catheters, the use of screening for asymptomatic individuals is recommended.

Indeed, there is a connection between the bladder and the umbilical cord before birth (via the urachus), which accounts for BC in less than $1 \%$ of people. When this relationship between the bladder and the umbilical cord persists after birth, the association becomes cancerous (Amin et al., 2014). A cancer originating from the urachus is usually the adenocarcinoma type made up of cancerous cells. More than $30 \%$ of bladder adenocarcinomas originate from this section (Jacobs et al., 2010). Another congenital defect that increases the risk of BC is exstrophy. In this anomaly, the bladder is completely out of the lower abdomen and the urethra is completely open. This malformation has a wide range. Its mild form, called epispadias, is the opening of the urethra in the lower portion at the back of the penis (Lee et al., 2014). In more severe forms, a longer opening surrounds the bladder neck and the bladder, and the hip bone is open at the front. These abnormalities are often seen in boys and often accompanied by abnormalities of the reproductive system and the anus. Surgery immediately after birth causes the bladder and abdominal wall to be closed (and repairs the related defects), but those who have not yet had a surgery are at higher risk for urinary tract infections and BC (Giron et al., 2011; Zhang et al., 2013).

\section{Conclusion}

The objective of this review is to investigate the incidence and mortality rates of $\mathrm{BC}$ in the world and the association between environmental risk factors and $\mathrm{BC}$ incidence. The findings of this study showed that BC incidence and mortality differed considerably according to geographic area. One of the main risk factors for $B C$ is smoking. The most important risk factor for developing $B C$ is occupational factors, in particular exposure to aromatic amines after smoking. Another risk factor is genetic susceptibility as BC risk is twice as high in firstdegree relatives than other patients. Nutritional factors, such as lack of adequate fluids, vitamin D deficiency, increased arsenic concentrations, and nitrates and disinfectants in drinking water play a significant role in the incidence of BC. There is a need for clinical trials to confirm the role of vitamin $D$ in reducing $B C$ incidence. Further studies are needed to confirm the role of nitrates in the incidence of $B C$. In terms of age, the risk of $B C$ increases with aging. Among the medically related $B C$ causes are infection with Schistosoma and the human papillomavirus. Use of radiation therapy, use of certain medications, persistent 
use of urinary catheters, and congenital defects are also associated with BC induction. Further studies are needed to investigate the mechanism of BC occurrence due to immunosuppressive drugs and anti-diabetes medications.

\section{Abbreviations}

BC: Bladder Cancer

ESRD: end-stage renal disease

GSTM1: glutathione S-transferase mu1

HPV: Human Papilloma Virus

HR: Hazard Ratio

MBOCA: 4,4'-methylene-bis(2-chloroaniline

NAT2: N-acetyltransferase 2

OR: Odds Ratio

SMR: standardized mortality ratio

UBV: ultraviolet B

\section{Author Contributions}

All authors contributed to the design of the research, AAT, FHS, AKR, SH, NNB extracted the data and summarized it. All authors drafted the first version. HSG, AMH and HS edited the first draft. All authors reviewed, commented and approved the final draft.

\section{References}

[Internet] (2017). Bladder Cancer. The Scripps Research Institute.

Abern, M.R., Dude, A.M., Tsivian, M., and Coogan, C.L. (2013). The characteristics of bladder cancer after radiotherapy for prostate cancer. Paper presented at: Urologic Oncology: Seminars and Original Investigations (Elsevier). https://doi.org/10.1016/ j.urolonc.2012.04.006

Aglianò, A. M., Gradilone, A., Gazzaniga, P., Napolitano, M., Vercillo, R., Albonici, L., . . Vecchione, A. (1994). High frequency of human papillomavirus detection in urinary bladder cancer. Urologia Internationalis, 53(3), 125-129. https://doi.org/ 10.1159/000282652

Alberg, A. J., \& Hébert, J. R. (2009). Cigarette smoking and bladder cancer: a new twist in an old saga? Oxford University Press. 
Amin, M. B., Smith, S. C., Eble, J. N., Rao, P., Choi, W. W., Tamboli, P., \& Young, R. H. (2014). Glandular neoplasms of the urachus: A report of 55 cases emphasizing mucinous cystic tumors with proposed classification. The American Journal of Surgical Pathology, 38(8), 1033-1045.

Antoni, S., Ferlay, J., Soerjomataram, I., Znaor, A., Jemal, A., \& Bray, F. (2017). Bladder cancer incidence and mortality: A global overview and recent trends. European Urology, 71(1), 96-108. https://doi.org/10.1016/j.eururo.2016.06.010

Baithun, S., Daruwala, P., \& Oliver, R. T. (1998). Squamous change in bladder cancer and its relevance to understanding clonal evolution in development of bladder cancer. Cancer Surveys, 31, 17-27.

Barghi, M. R., Rahjoo, T., Borghei, M., Hosseini-Moghaddam, S. M., Amani, D., \& Farrokhi, B. (2012). Association between the evidence of human papilloma virus infection in bladder transitional cell carcinoma in men and cervical dysplasia in their spouses. Archives of Iranian Medicine, 15(9), 572-574.

Baris, D., Karagas, M. R., Verrill, C., Johnson, A., Andrew, A. S., Marsit, C. J., . . . Silverman, D. T. (2009). A case-control study of smoking and bladder cancer risk: Emergent patterns over time. Journal of the National Cancer Institute, 101(22), 15531561. https://doi.org/10.1093/jnci/djp361

Bosetti, C., Bertuccio, P., Chatenoud, L., Negri, E., La Vecchia, C., \& Levi, F. (2011). Trends in mortality from urologic cancers in Europe, 1970-2008. European Urology, 60(1), 115. https://doi.org/10.1016/j.eururo.2011.03.047

Botelho, M., Ferreira, A. C., Oliveira, M. J., Domingues, A., Machado, J. C., \& da Costa, J. M. C. (2009). Schistosoma haematobium total antigen induces increased proliferation, migration and invasion, and decreases apoptosis of normal epithelial cells. International Journal for Parasitology, 39(10), 1083-1091. https://doi.org/10.1016/ j.ijpara.2009.02.016

Botelho, M.C., Oliveira, P.A., Lopes, C., da Costa, J.M.C., and Machado, J.C. (2011). Urothelial dysplasia and inflammation induced by Schistosoma haematobium total antigen instillation in mice normal urothelium. Paper presented at: Urologic Oncology: Seminars and Original Investigations (Elsevier). https://doi.org/10.1016/j.urolonc. 2009.09.017

Brinkman, M. T., Karagas, M. R., Zens, M. S., Schned, A., Reulen, R. C., \& Zeegers, M. P. (2010). Minerals and vitamins and the risk of bladder cancer: Results from the New Hampshire Study. Cancer Causes \& Control, 21(4), 609-619. https://doi.org/10.1007/ s10552-009-9490-0

Brown, A.P., Neeley, E.S., Werner, T., Soisson, A.P., Burt, R.W., and Gaffney, D.K. (2010). A population-based study of subsequent primary malignancies after endometrial cancer: genetic, environmental, and treatment-related associations. International Journal of Radiation Oncology* Biology* Physics 78, 127-135. https://doi.org/10.1016/j.jjrobp. $\underline{2009.07 .1692}$

Burger, M., Catto, J. W., Dalbagni, G., Grossman, H. B., Herr, H., Karakiewicz, P., . . Lotan, Y. (2013). Epidemiology and risk factors of urothelial bladder cancer. European Urology, 63(2), 234-241. https://doi.org/10.1016/j.eururo.2012.07.033

Carreón, T., Hein, M. J., Viet, S. M., Hanley, K. W., Ruder, A. M., \& Ward, E. M. (2010). Increased bladder cancer risk among workers exposed to o-toluidine and aniline: $A$ reanalysis. Occupational and Environmental Medicine, 67(5), 348-350. https://doi.org/ $\underline{10.1136 / \mathrm{oem} .2009 .051136}$ 
Case, R. A., \& Hosker, M. E. (1954). Tumour of the urinary bladder as an occupational disease in the rubber industry in England and Wales. British Journal of Preventive \& Social Medicine, 8(2), 39-50.

Chavan, S., Bray, F., Lortet-Tieulent, J., Goodman, M., \& Jemal, A. (2014). International variations in bladder cancer incidence and mortality. European Urology, 66(1), 59-73. https://doi.org/10.1016/j.eururo.2013.10.001

Chen, C.-H., Dickman, K. G., Moriya, M., Zavadil, J., Sidorenko, V. S., Edwards, K. L., . . Grollman, A. P. (2012). Aristolochic acid-associated urothelial cancer in Taiwan. Proceedings of the National Academy of Sciences of the United States of America, 109(21), 8241-8246. https://doi.org/10.1073/pnas.1119920109

Chen, C. H., Dickman, K. G., Huang, C. Y., Moriya, M., Shun, C. T., Tai, H. C., . . Pu, Y. S. (2013). Aristolochic acid-induced upper tract urothelial carcinoma in Taiwan: Clinical characteristics and outcomes. International Journal of Cancer, 133(1), 14-20. https:// doi.org/10.1002/ijc.28013

Chen, H.-I., Chi, T.-C., Ko, S.-Y., Hsu, Y.-C., Lin, I.-H., Chen, A., . . Li, C.-F. (2014). 4, 4'Methylenebis (2-chloroaniline)(MBOCA) May Be Highly Toxic and a Carcinogen Based on an Experimental Study with Mice. Advances in Biological Chemistry, 4(03), 203-213. https://doi.org/10.4236/abc.2014.43025

Chen, W., Clements, M., Rahman, B., Zhang, S., Qiao, Y., \& Armstrong, B. K. (2010). Relationship between cancer mortality/incidence and ambient ultraviolet $\mathrm{B}$ irradiance in China. Cancer Causes \& Control, 21(10), 1701-1709. https://doi.org/10.1007/ s10552-010-9599-1

Chiu, H.-F., Tsai, S.-S., \& Yang, C.-Y. (2007). Nitrate in drinking water and risk of death from bladder cancer: An ecological case-control study in Taiwan. Journal of Toxicology and Environmental Health. Part A., 70(12), 1000-1004. https://doi.org/ 10.1080/15287390601171801

Chow, W.-H., Dong, L. M., \& Devesa, S. S. (2010). Epidemiology and risk factors for kidney cancer. Nature Reviews. Urology, 7(5), 245-257. https://doi.org/10.1038/nrurol. 2010.46

Clyne, M. (2013). Bladder cancer: Aristolochic acid-one of the most potent carcinogens known to man. Nature Reviews. Urology, 10(10), 552-552. https://doi.org/ 10.1038/nrurol.2013.186

Colombel, M., Soloway, M., Akaza, H., Böhle, A., Palou, J., Buckley, R., Lamm, D., Brausi, M., Witjes, J.A., and Persad, R. (2008). Epidemiology, staging, grading, and risk stratification of bladder cancer. european urology supplements 7, 618-626.

Colt, J.S., Karagas, M.R., Schwenn, M., Baris, D., Johnson, A., Stewart, P., Verrill, C., Moore, L.E., Lubin, J., and Ward, M.H. (2010). Occupation and bladder cancer in a population-based case-control study in Northern New England. Occupational and environmental medicine, oem. 2009.052571.

Datta, G. D., Neville, B. A., Kawachi, I., Datta, N. S., \& Earle, C. C. (2009). Marital status and survival following bladder cancer. Journal of Epidemiology and Community Health, 63(10), 807-813. https://doi.org/10.1136/jech.2008.082438

Davis-Dao, C.A., Henderson, K.D., Sullivan-Halley, J., Ma, H., West, D.W., Xiang, Y.-B., Gago-Dominguez, M., Stern, M.C., Castelao, J.E., and Conti, D.V. (2011). Lower risk in parous women suggests hormonal factors important in bladder cancer etiology. Cancer Epidemiology and Prevention Biomarkers, cebp. 0017.2011. https://doi.org/ 10.1158/1055-9965.EPI-11-0017 
Dietrich, K., Demidenko, E., Schned, A., Zens, M. S., Heaney, J., \& Karagas, M. R. (2011). Parity, early menopause and the incidence of bladder cancer in women: A case-control study and meta-analysis. European Journal of Cancer, 47(4), 592-599. https://doi.org/ 10.1016/j.ejca.2010.10.007

Emadi, A., Jones, R. J., \& Brodsky, R. A. (2009). Cyclophosphamide and cancer: Golden anniversary. Nature Reviews. Clinical Oncology, 6(11), 638-647. https://doi.org/ 10.1038/nrclinonc.2009.146

Escudero, D. O., Shirodkar, S. P., \& Lokeshwar, V. B. (2011). Bladder carcinogenesis and molecular pathways. In Bladder Tumors (pp. 23-41). Springer. https://doi.org/ 10.1007/978-1-60761-928-4_2

Feifer, A. H., Taylor, J. M., Tarin, T. V., \& Herr, H. W. (2011). Maximizing cure for muscleinvasive bladder cancer: Integration of surgery and chemotherapy. European Urology, 59(6), 978-984. https://doi.org/10.1016/j.eururo.2011.01.014

Ferlay, J., Steliarova-Foucher, E., Lortet-Tieulent, J., Rosso, S., Coebergh, J. W., Comber, H., . . Bray, F. (2013). Cancer incidence and mortality patterns in Europe: Estimates for 40 countries in 2012. European Journal of Cancer, 49(6), 1374-1403. https://doi.org/ 10.1016/j.ejca.2012.12.027

Fernández, M. I., López, J. F., Vivaldi, B., \& Coz, F. (2012). Long-term impact of arsenic in drinking water on bladder cancer health care and mortality rates 20 years after end of exposure. The Journal of Urology, 187(3), 856-861. https://doi.org/10.1016/j.juro. 2011.10.157

Figueroa, J. D., Koutros, S., Colt, J. S., Kogevinas, M., Garcia-Closas, M., Real, F. X., . . Silverman, D. T. (2015). Modification of occupational exposures on bladder cancer risk by common genetic polymorphisms. JNCl. Journal of the National Cancer Institute, 107(11), 107. https://doi.org/10.1093/jnci/djv223

Freedman, N. D., Silverman, D. T., Hollenbeck, A. R., Schatzkin, A., \& Abnet, C. C. (2011). Association between smoking and risk of bladder cancer among men and women. Journal of the American Medical Association, 306(7), 737-745. https://doi.org/10.1001/ jama.2011.1142

Gago-Dominguez, M., Castelao, J. E., Yuan, J. M., Yu, M. C., \& Ross, R. K. (2001). Use of permanent hair dyes and bladder-cancer risk. International Journal of Cancer, 91(4), 575-579. https://doi.org/10.1002/1097-0215(200002)9999:99993.0.CO;2-S

García-Pérez, J., Pollán, M., Boldo, E., Pérez-Gómez, B., Aragonés, N., Lope, V., . . . López-Abente, G. (2009). Mortality due to lung, laryngeal and bladder cancer in towns lying in the vicinity of combustion installations. The Science of the Total Environment, 407(8), 2593-2602. https://doi.org/10.1016/j.scitotenv.2008.12.062

Garland, C., Shekelle, R. B., Barrett-Connor, E., Criqui, M. H., Rossof, A. H., \& Paul, O. (1985). Dietary vitamin D and calcium and risk of colorectal cancer: A 19-year prospective study in men. Lancet, 1(8424), 307-309. https://doi.org/10.1016/ S0140-6736(85)91082-7

Giron, A. M., Passerotti, C. C., Nguyen, H., Cruz, J. A., \& Srougi, M. (2011). Bladder exstrophy: Reconstructed female patients achieving normal pregnancy and delivering normal babies. International Braz J Urol, 37(5), 605-610. https://doi.org/10.1590/ S1677-55382011000500006

Golka, K., Wiese, A., Assennato, G., \& Bolt, H. M. (2004). Occupational exposure and urological cancer. World Journal of Urology, 21(6), 382-391. https://doi.org/10.1007/ s00345-003-0377-5 
Gulis, G., Czompolyova, M., \& Cerhan, J. R. (2002). An ecologic study of nitrate in municipal drinking water and cancer incidence in Trnava District, Slovakia. Environmental Research, 88(3), 182-187. https://doi.org/10.1006/enrs.2002.4331

Husain, E., Prowse, D. M., Ktori, E., Shaikh, T., Yaqoob, M., Junaid, I., \& Baithun, S. (2009). Human papillomavirus is detected in transitional cell carcinoma arising in renal transplant recipients. Pathology, 41(3), 245-247. https://doi.org/ 10.1080/00313020902756303

Jacobs, B. L., Lee, C. T., \& Montie, J. E. (2010). Bladder cancer in 2010: How far have we come? CA: a Cancer Journal for Clinicians, 60(4), 244-272. https://doi.org/10.3322/ caac. 20077

Jemal, A., Bray, F., Center, M. M., Ferlay, J., Ward, E., \& Forman, D. (2011). Global cancer statistics. CA: a Cancer Journal for Clinicians, 61(2), 69-90. https://doi.org/10.3322/ caac. 20107

Jemal, A., Center, M. M., DeSantis, C., \& Ward, E. M. (2010). Global patterns of cancer incidence and mortality rates and trends. Cancer Epidemiology and Prevention Biomarkers, 19(8), 1893-1907. https://doi.org/10.1158/1055-9965.EPI-10-0437

Jomova, K., Jenisova, Z., Feszterova, M., Baros, S., Liska, J., Hudecova, D., . . Valko, M. (2011). Arsenic: Toxicity, oxidative stress and human disease. Journal of Applied Toxicology, 31(2), 95-107.

Karagas, M. R., Park, S., Warren, A., Hamilton, J., Nelson, H. H., Mott, L. A., \& Kelsey, K. T. (2005). Gender, smoking, glutathione-S-transferase variants and bladder cancer incidence: A population-based study. Cancer Letters, 219(1), 63-69. https://doi.org/ 10.1016/j.canlet.2004.10.006

Kiemeney, L. A., Sulem, P., Besenbacher, S., Vermeulen, S. H., Sigurdsson, A., Thorleifsson, G., . . Stefansson, K. (2010). A sequence variant at 4p16.3 confers susceptibility to urinary bladder cancer. Nature Genetics, 42(5), 415-419. https:// doi.org/10.1038/ng.558

Kiriluk, K.J., Prasad, S.M., Patel, A.R., Steinberg, G.D., and Smith, N.D. (2012). Bladder cancer risk from occupational and environmental exposures. Paper presented at: Urologic Oncology: Seminars and Original Investigations (Elsevier). https://doi.org/ 10.1016/j.urolonc.2011.10.010

Kirkali, Z., Chan, T., Manoharan, M., Algaba, F., Busch, C., Cheng, L., . . Weider, J. (2005). Bladder cancer: Epidemiology, staging and grading, and diagnosis. Urology, 66(6, Suppl 1), 4-34. https://doi.org/10.1016/j.urology.2005.07.062

Koay, E. J., Teh, B. S., Paulino, A. C., \& Butler, E. B. (2011). A Surveillance, Epidemiology, and End Results analysis of small cell carcinoma of the bladder: Epidemiology, prognostic variables, and treatment trends. Cancer, 117(23), 5325-5333. https:// doi.org/10.1002/cncr.26197

Kogevinas M, G.-C.M. (2014). Bladder cancer. In Occupational Cancers (Springer), pp. 461-480.

Koroukian, S., Bakkaki, P., and Raghavan, D. (2010). Survival disparities by Medicaid status: An analysis of 8 cancers [abstract A-62]. Paper presented at: American Association of Cancer Research Annual Meeting, Miami, Florida.

Lee, R. K., Abol-Enein, H., Artibani, W., Bochner, B., Dalbagni, G., Daneshmand, S., . . Shariat, S. F. (2014). Urinary diversion after radical cystectomy for bladder cancer: Options, patient selection, and outcomes. BJU International, 113(1), 11-23. https:// doi.org/10.1111/bju.12121 
Letašiová, S., Medve'ová, A., Šovčíková, A., Dušinská, M., Volkovová, K., Mosoiu, C., \& Bartonová, A. (2012). Bladder cancer, a review of the environmental risk factors. Environmental Health, 11(Suppl 1), S11. https://doi.org/10.1186/1476-069X-11-S1-S11 Levin, D., Bell, S., Sund, R., Hartikainen, S. A., Tuomilehto, J., Pukkala, E., ... Colhoun, H. M., \& the Scottish Diabetes Research Network Epidemiology Group, \& the Diabetes and Cancer Research Consortium. (2015). Pioglitazone and bladder cancer risk: A multipopulation pooled, cumulative exposure analysis. Diabetologia, 58(3), 493-504. https://doi.org/10.1007/s00125-014-3456-9

Lewis, J. D., Ferrara, A., Peng, T., Hedderson, M., Bilker, W. B., Quesenberry, C. P., Jr., . . Strom, B. L. (2011). Risk of bladder cancer among diabetic patients treated with pioglitazone: Interim report of a longitudinal cohort study. Diabetes Care, 34(4), 916922. https://doi.org/10.2337/dc10-1068

Li, N., Yang, L., Zhang, Y., Zhao, P., Zheng, T., \& Dai, M. (2011). Human papillomavirus infection and bladder cancer risk: A meta-analysis. The Journal of Infectious Diseases, 204(2), 217-223. https://doi.org/10.1093/infdis/jir248

Lin, I.-S., Fan, P.-L., Chen, H.-I., Loh, C.-H., Shih, T.-S., \& Liou, S.-H. (2013). Rapid and intermediate $\mathrm{N}$-acetylators are less susceptible to oxidative damage among 4,4'. methylenebis(2-chloroaniline) (MBOCA)-exposed workers. International Journal of Hygiene and Environmental Health, 216(4), 515-520. https://doi.org/10.1016/j.ijheh. $\underline{2013.02 .001}$

Mahdavifar, N., Ghoncheh, M., Pakzad, R., Momenimovahed, Z., \& Salehiniya, H. (2016). Epidemiology, incidence and mortality of bladder cancer and their relationship with the development index in the world. Asian Pacific Journal of Cancer Prevention, 17(1), 381-386. https://doi.org/10.7314/APJCP.2016.17.1.381

Melick, W. F., Escue, H. M., Naryka, J. J., Mezera, R. A., \& Wheeler, E. P. (1955). The first reported cases of human bladder tumors due to a new carcinogen-xenylamine. The Journal of Urology, 74(6), 760-766. https://doi.org/10.1016/S0022-5347(17)67344-0

Meliker, J. R., Slotnick, M. J., AvRuskin, G. A., Schottenfeld, D., Jacquez, G. M., Wilson, M. L., ... Nriagu, J. O. (2010). Lifetime exposure to arsenic in drinking water and bladder cancer: A population-based case-control study in Michigan, USA. Cancer Causes \& Control, 21(5), 745-757. https://doi.org/10.1007/s10552-010-9503-z

Miao, Y., Everly, J. J., Gross, T. G., Tevar, A. D., First, M. R., Alloway, R. R., \& Woodle, E. S. (2009). De novo cancers arising in organ transplant recipients are associated with adverse outcomes compared with the general population. Transplantation, 87(9), 13471359. https://doi.org/10.1097/TP.0b013e3181a238f6

Mohr, S. B., Garland, C. F., Gorham, E. D., Grant, W. B., \& Garland, F. C. (2010). Ultraviolet $B$ irradiance and incidence rates of bladder cancer in 174 countries. American Journal of Preventive Medicine, 38(3), 296-302. https://doi.org/10.1016/ j.amepre.2009.10.044

Monach, P. A., Arnold, L. M., \& Merkel, P. A. (2010). Incidence and prevention of bladder toxicity from cyclophosphamide in the treatment of rheumatic diseases: A data-driven review. Arthritis \& Rheumatology (Hoboken, N.J.), 62(1), 9-21. https://doi.org/10.1002/ art.25061

Naranmandura, H., Carew, M. W., Xu, S., Lee, J., Leslie, E. M., Weinfeld, M., \& Le, X. C. (2011). Comparative toxicity of arsenic metabolites in human bladder cancer EJ-1 cells. Chemical Research in Toxicology, 24(9), 1586-1596. https://doi.org/10.1021/tx200291p 
Noël, J. C., Thiry, L., Verhest, A., Deschepper, N., Peny, M.-O., Sattar, A. A., . . Haot, J. (1994). Transitional cell carcinoma of the bladder: Evaluation of the role of human papillomaviruses. Urology, 44(5), 671-675. https://doi.org/10.1016/ S0090-4295(94)80202-5

Pakzad, R., Mohammadian-Hafshejani, A., Mohammadian, M., Pakzad, I., Safiri, S., Khazaei, S., \& Salehiniya, H. (2015). Incidence and mortality of bladder cancer and their relationship with development in Asia. Asian Pacific Journal of Cancer Prevention, 16(16), 7365-7374. https://doi.org/10.7314/APJCP.2015.16.16.7365

Pannek, J. (2002). Transitional cell carcinoma in patients with spinal cord injury: A high risk malignancy? Urology, 59(2), 240-244. https://doi.org/10.1016/ S0090-4295(01)01495-9

Peralta-Videa, J. R., Lopez, M. L., Narayan, M., Saupe, G., \& Gardea-Torresdey, J. (2009). The biochemistry of environmental heavy metal uptake by plants: Implications for the food chain. The International Journal of Biochemistry \& Cell Biology, 41(8-9), 16651677. https://doi.org/10.1016/j.biocel.2009.03.005

Pira, E., Piolatto, G., Negri, E., Romano, C., Boffetta, P., Lipworth, L., . . . La Vecchia, C. (2010). Bladder cancer mortality of workers exposed to aromatic amines: A 58-year follow-up. Journal of the National Cancer Institute, 102(14), 1096-1099. https://doi.org/ 10.1093/jnci/djq214

Ranasinghe, W. K., De Silva, D., De Silva, M. V., Ranasinghe, T. I., Lawrentschuk, N., Bolton, D., \& Persad, R. (2012). Incidence of bladder cancer in sri lanka: Analysis of the cancer registry data and review of the incidence of bladder cancer in the South asian population. Korean Journal of Urology, 53(5), 304-309. https://doi.org/10.4111/kju. 2012.53.5.304

Reid, L. M., Leav, I., Kwan, P. W., Russell, P., \& Merk, F. B. (1984). Characterization of a human, sex steroid-responsive transitional cell carcinoma maintained as a tumor line (R198) in athymic nude mice. Cancer Research, 44(10), 4560-4573.

Ros, M. M., Bas Bueno-de-Mesquita, H. B., Büchner, F. L., Aben, K. K., Kampman, E., Egevad, L., ... Riboli, E. (2011). Fluid intake and the risk of urothelial cell carcinomas in the European Prospective Investigation into Cancer and Nutrition (EPIC). International Journal of Cancer, 128(11), 2695-2708. https://doi.org/10.1002/ijc.25592

Scosyrev, E., Noyes, K., Feng, C., \& Messing, E. (2009). Sex and racial differences in bladder cancer presentation and mortality in the US. Cancer, 115(1), 68-74. https:// doi.org/10.1002/cncr.23986

Shamseddine, A., Saleh, A., Charafeddine, M., Seoud, M., Mukherji, D., Temraz, S., \& Sibai, A. M. (2014). Cancer trends in Lebanon: A review of incidence rates for the period of 2003-2008 and projections until 2018. Population Health Metrics, 12(1), 4. https://doi.org/10.1186/1478-7954-12-4

Sievert, K. D., Amend, B., Nagele, U., Schilling, D., Bedke, J., Horstmann, M., ... Stenzl, A. (2009). Economic aspects of bladder cancer: What are the benefits and costs? World Journal of Urology, 27(3), 295-300. https://doi.org/10.1007/s00345-009-0395-z

Simone, G., \& Gallucci, M. (2012). Multimodality treatment versus radical cystectomy: bladder sparing at cost of life? Elsevier.

Steinmaus, C., Yuan, Y., Bates, M. N., \& Smith, A. H. (2003). Case-control study of bladder cancer and drinking water arsenic in the western United States. American Journal of Epidemiology, 158(12), 1193-1201. https://doi.org/10.1093/aje/kwg281 
Sylvester, R. J. (2011). How well can you actually predict which non-muscle-invasive bladder cancer patients will progress? European Urology, 60(3), 431-433. https:// doi.org/10.1016/j.eururo.2011.06.001

Tapio, S., \& Grosche, B. (2006). Arsenic in the aetiology of cancer. Mutation Research/ Reviews in Mutation Research, 612(3), 215-246. https://doi.org/10.1016/j.mrrev. 2006.02.001

Torre, L. A., Bray, F., Siegel, R. L., Ferlay, J., Lortet-Tieulent, J., \& Jemal, A. (2015). Global cancer statistics, 2012. CA: a Cancer Journal for Clinicians, 65(2), 87-108. https:// doi.org/10.3322/caac. 21262

Vajdic, C. M., McDonald, S. P., McCredie, M. R., van Leeuwen, M. T., Stewart, J. H., Law, M., ... Grulich, A. E. (2006). Cancer incidence before and after kidney transplantation. Journal of the American Medical Association, 296(23), 2823-2831. https://doi.org/ 10.1001/jama.296.23.2823

Volanis, D., Kadiyska, T., Galanis, A., Delakas, D., Logotheti, S., \& Zoumpourlis, V. (2010). Environmental factors and genetic susceptibility promote urinary bladder cancer. Toxicology Letters, 193(2), 131-137. https://doi.org/10.1016/j.toxlet.2009.12.018

W., P. (2001). Nitrate in drinking water and human health. Iowa City. Center for Health Effects of Environmental Contamination.

Ward, M. H., Cantor, K. P., Riley, D., Merkle, S., \& Lynch, C. F. (2003). Nitrate in public water supplies and risk of bladder cancer. Epidemiology (Cambridge, Mass.), 14(2), 183-190. https://doi.org/10.1097/01.EDE.0000050664.28048.DF

Weyer, P. J., Cerhan, J. R., Kross, B. C., Hallberg, G. R., Kantamneni, J., Breuer, G., . . Lynch, C. F. (2001). Municipal drinking water nitrate level and cancer risk in older women: The lowa Women's Health Study. Epidemiology (Cambridge, Mass.), 12(3), 327-338. https://doi.org/10.1097/00001648-200105000-00013

Yee, D. S., Ishill, N. M., Lowrance, W. T., Herr, H. W., \& Elkin, E. B. (2011). Ethnic differences in bladder cancer survival. Urology, 78(3), 544-549. https://doi.org/ 10.1016/j.urology.2011.02.042

Youshya, S., Purdie, K., Breuer, J., Proby, C., Sheaf, M. T., Oliver, R. T., \& Baithun, S. (2005). Does human papillomavirus play a role in the development of bladder transitional cell carcinoma? A comparison of PCR and immunohistochemical analysis. Journal of Clinical Pathology, 58(2), 207-210. https://doi.org/10.1136/jcp.2004.017152 Zeegers, M. P., Kellen, E., Buntinx, F., \& van den Brandt, P. A. (2004). The association between smoking, beverage consumption, diet and bladder cancer: A systematic literature review. World Journal of Urology, 21(6), 392-401. https://doi.org/10.1007/ s00345-003-0382-8

Zeegers, M. P., Selen, R. F., Kleinjans, J. C., Goldbohm, R. A., \& van den Brandt, P. A. (2006). Nitrate intake does not influence bladder cancer risk: The Netherlands cohort study. Environmental Health Perspectives, 114(10), 1527-1531. https://doi.org/10.1289/ ehp.9098

Zhang, H., Jiang, H., Wu, Z., Fang, Z., Fan, J., \& Ding, Q. (2013). Primary adenocarcinoma of the urinary bladder: A single site analysis of 21 cases. International Urology and Nephrology, 45(1), 107-111. https://doi.org/10.1007/s11255-012-0305-y 